\title{
Bilateral cerebellar hemorrhage in vermian vein thrombosis
}

Figure $1 \quad$ CT and axial MRI
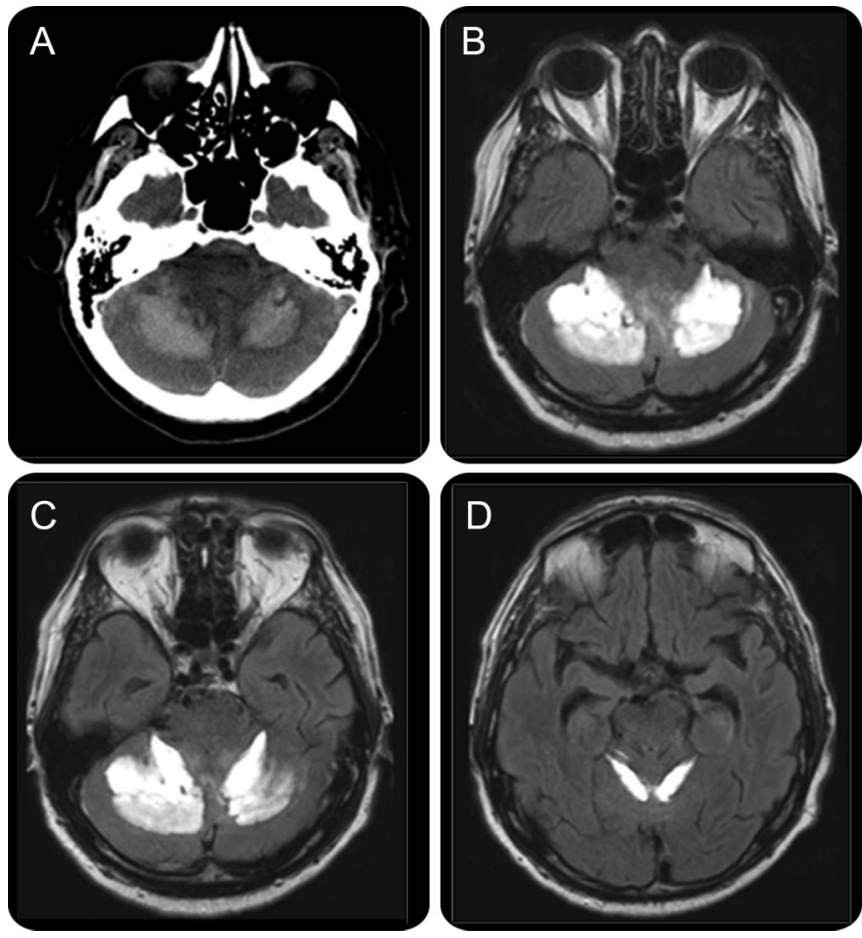

CT (A) and fluid-attenuated inversion recovery MRI (B, C, D) show bilateral cerebellar hemorrhage.

Figure 2 Sagittal T1 MRI before and after contrast
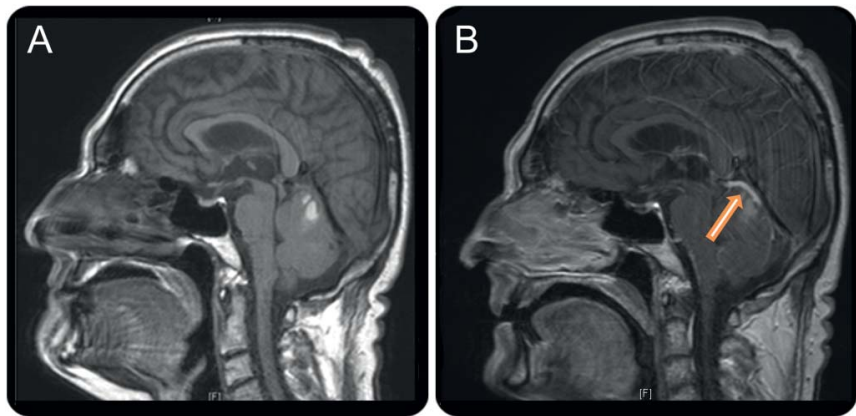

(A) Before contrast. (B) After contrast. Sequence after contrast administration shows enhancement of the superior vermian vein (arrow). These findings are suggestive for thrombosis.

A 67-year-old previously healthy man presented with sudden onset of headache, vomiting, and instability of stance and gait. Neurologic examination demonstrated bilateral dysmetria of the limbs, ataxia, and scanning speech. Neuroimaging showed bilateral cerebellar hemorrhage and altered signal of the superior vermian vein suggestive for thrombosis (figures 1 and 2). Workup for hematologic, coagulation, and immunologic disorders was negative. 
Simultaneous bilateral cerebellar hemorrhage is extremely rare, especially without known precipitants such as hypertension, vascular anomalies, tumors, congophilic angiopathy, vasculitis, coagulopathy, and illicit drug use. $^{1,2}$

Simona Lattanzi, MD, Leandro Provinciali, MD, Mauro Silvestrini, MD

From the Neurological Clinic, Department of Experimental and Clinical Medicine, Marche Polytechnic University, Ancona, Italy.

Author contributions: Dr. Lattanzi: drafting/revising the manuscript, study concept or design, analysis or interpretation of data, accepts responsibility for conduct of research and final approval. Professor Provinciali: drafting/revising the manuscript, study concept or design, accepts responsibility for conduct of research and final approval. Professor Silvestrini: drafting/revising the manuscript, study concept or design, accepts responsibility for conduct of research and final approval, study supervision.

Acknowledgment: The authors thank Dr. Francesca Lupidi (Neurological Clinic, University Hospital of Ancona, Italy) and Dr. Natalie Herber (Department of Neuroradiology, University Hospital of Ancona, Italy) for editing assistance.

Study funding: No targeted funding reported.

Disclosure: The authors report no disclosures relevant to the manuscript. Go to Neurology.org for full disclosures.

Correspondence to Dr. Lattanzi: alfierelattanzisimona@gmail.com

1. Thrift AG, Donnan GA, McNeil JJ. Epidemiology of intracerebral hemorrhage. Epidemiol Rev 1995;17:361-381.

2. Auer RN, Sutherland GR. Primary intracerebral hemorrhage: pathophysiology. Can J Neurol Sci 2005;32(suppl 2):S3-S12.

\section{NeuroImages Are Free at www.neurology.org!}

All Neurology ${ }^{\circledR}$ NeuroImages can now be freely accessed on the Neurology Web site. See them at www.neurology.org, where you can also sign up for journal email alerts and check out other online features, including the Resident \& Fellow section, Neurology: Clinical Practice, and the weekly Neurology Podcasts. 


\title{
Neurology
}

\author{
Bilateral cerebellar hemorrhage in vermian vein thrombosis \\ Simona Lattanzi, Leandro Provinciali and Mauro Silvestrini \\ Neurology 2013;81;1364-1365 \\ DOI 10.1212/WNL.0b013e3182a824e1
}

This information is current as of October 7, 2013

Updated Information \&
Services

References

Subspecialty Collections

Permissions \& Licensing

Reprints including high resolution figures, can be found at: http://n.neurology.org/content/81/15/1364.full

This article cites 2 articles, 0 of which you can access for free at: http://n.neurology.org/content/81/15/1364.full\#ref-list-1

This article, along with others on similar topics, appears in the following collection(s):

All Cerebrovascular disease/Stroke

http://n.neurology.org/cgi/collection/all_cerebrovascular_disease_strok

e

Cerebral venous thrombosis

http://n.neurology.org/cgi/collection/cerebral_venous_thrombosis

Intracerebral hemorrhage

http://n.neurology.org/cgi/collection/intracerebral_hemorrhage

Information about reproducing this article in parts (figures,tables) or in its entirety can be found online at:

http://www.neurology.org/about/about_the_journal\#permissions

Information about ordering reprints can be found online:

http://n.neurology.org/subscribers/advertise

Neurology ${ }^{\circledR}$ is the official journal of the American Academy of Neurology. Published continuously since 1951, it is now a weekly with 48 issues per year. Copyright @ 2013 American Academy of Neurology. All rights reserved. Print ISSN: 0028-3878. Online ISSN: 1526-632X.

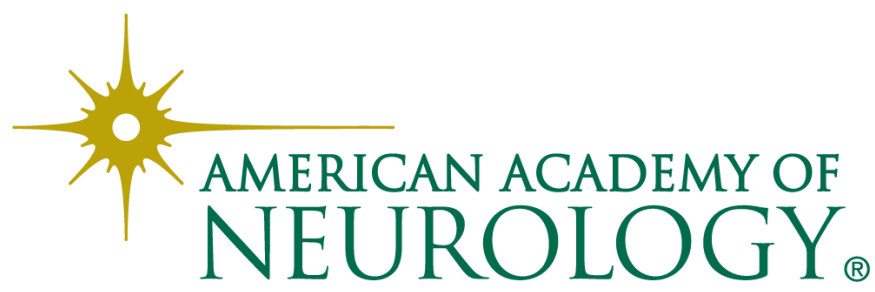

